\title{
Improved The Emphaty Through Techniques Photovoice In Family Dusun Alas Timur Bawean Gresik
}

\author{
Authors \\ Wenti Krisnawati ${ }^{1 .}$ Eka Wahyu Nur Fajariyah A. ${ }^{2}$,Dzuhriawan Farrikh ${ }^{3}$ \\ Correspondence \\ ${ }^{1}$ Management Study Program, Universitas of Muhammadiyah Gresik \\ ${ }^{2,3}$ Psychology Study Program, University of Muhammadiyah Gresik \\ wentikrisnawati@umg.ac.id,ekawahyunurf98@gmail.com ${ }^{1}$, farrikh.dzuhriawan1997@gmail.com²
}

\begin{abstract}
Most people who live on Bawean Island go abroad to earn a living and study. so they must be willing to leave their families to achieve their coveted dreams. Often the nomads' family will miss him and vice versa the nomads also miss his family. What is unexpected is that in most homes, family photographs are rarely found, even though their benefits can be used as medicine if they miss family members who are migrating. Therefore, the presence of family photos is expected to increase empathy which indicates harmony in a family. This program was carried out on August 24, 2019 by visiting residents' homes in accordance with the agreed time during the survey in advance.
\end{abstract}

Keywords: Empathy, Photovoice, Bawean, Residents' Homes, Family.

Received: 15 Januari 2020. Accepted: 20 Januari 2020.

\section{Introduction}

Humans are social creatures, they cannot live alone without the help of others. Likewise with family, every family member certainly needs help from other family members. However, in a family it is not possible to be together forever, surely some of them will split up to make a living and study.

In everyday life it is never free to make contact with other people, either interacting or just greeting one another. According to Pearson (1983) humans are social creatures. The expression has the meaning that as social beings, we cannot establish relationships alone, we always establish relationships with others, try to recognize and understand each other's needs, form interactions, and try to maintain those interactions (Sarlito W. Sarwono, 2009: 67). This is in accordance with the opinion of C. Asri Budiningsih (2004: 48) which states that the ability to empathize is very important in establishing relationships with others or relationships, this ability aims to understand the feelings of others, accept other people's perspectives, appreciate differences in people's feelings towards various things, be a good listener and questioner.
This is in accordance with the situation and condition of the people who live on Bawean Island. Many of them are reluctant to leave their families to earn a living by sailing and migrating abroad, and some are studying outside the island to reach their desired goals.

Several previous studies that examined the relationship between empathy, friendship, and the ability to deal with problems in the family showed that the ability to empathize and have many friends can support the formation of the ability to deal with problems (Nailul Fauziah, 2014).

Other research shows that the influence of empathy and self-control together on aggressiveness. This means that someone who has an attitude of empathy and self-control will reduce the existence of aggressiveness (Lailatul Badriyah, 2013). According to the above research the impact of empathy is to support the formation of good abilities in dealing with problems and can reduce aggressiveness.

During the implementation of the Real Work Lecture (KKN) in July-August 2019 in Alas Timur Bawean Gresik Hamlet, based on 
observations we have done, there are several families who show an attitude of empathy. .

Photovoice also aims for people to record and reflect on all their activities, in addition to that people gain insight because they not only take photos but also discuss them in situations and conditions. Based on the results of these discussions will make people have a new understanding or outlook and are expected to bring changes to the person's condition.

If it is related to the provision of guidance and counseling services, this technique photovoice is also suitable for personal and social services besides empathy is also included in the guidance and counseling services in the private and social fields.

Based on the description above, it is important to do a work program on "Increasing Empathy ThroughTechniques Photovoice to the families of Alas Timur Bawean Gresik Hamlet". The concept we use in taking family photos is a natural concept. That is because we want to build a photovoice with actual conditions without any background engineering and family circumstances so that it can give a natural impression.

\section{Method}

\section{Time and Place}

Technicalin carrying out Photovoice thison August 20, 2019 conducted a survey and visited the families who would be targeted to take family photos and ask for time to gather family members. The second is that on August 24,2019 we went to the family to be targeted and carried out a group photo in accordance with the agreed time in advance.

\section{Implementation Stage}

The several stages we carried out in implementing the family photo program include the following:

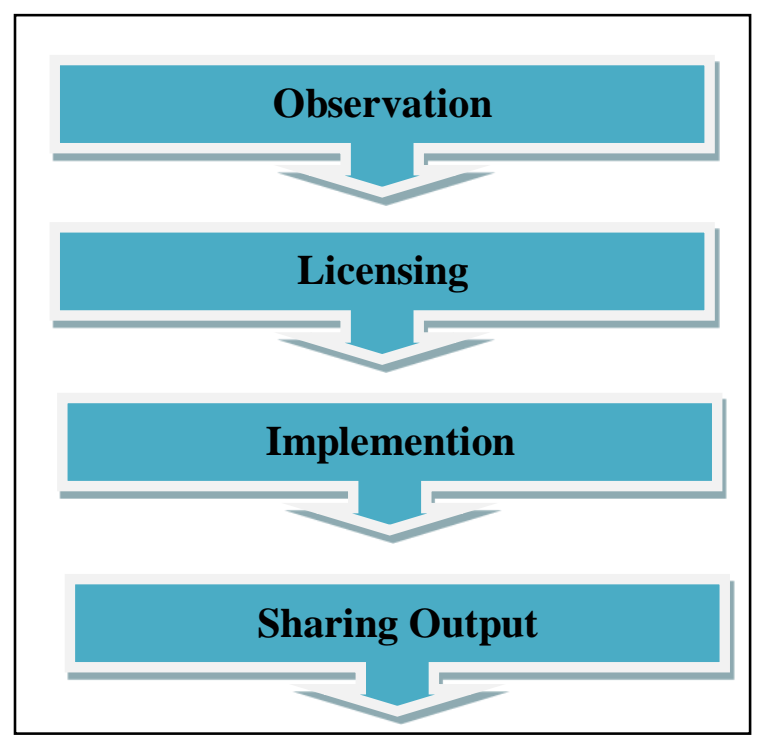

Figure 1. The several stages we carried out in implementing the family photo.

\section{Field Observation}

Before carrying out the family photo program, we first conducted a survey looking for families who fall into the criteria for carrying out family photos.

\section{Licensing}

After conducting field observations, we went to families who had entered the criteria and asked for permission to carry out family photos. When given permission, we ask for the time to carry out family photos.

\section{Implementation}

After obtaining permission from the target family, a family photo program was agreed upon the day and time in advance.

\section{Distribution of Family Photos}

After the family photo program has been implemented, the photos are printed and distributed to families who have been targeted by the family photo program.

\section{Results and Discussion}

The results of the implementation of thetechnique photovoice as revealed in the previous sub-chapter that photovoice can increase the empathy of family members. Improvements to the above results are also supported by the results of observations and interviews that show a change in empathy. 
Based on the results of interviews and observations of changes that appear to the family after being given an action that is, the family looks more concerned with other family members verbally and non-verbally. The change in attitude is also shown by the awareness of family members of the importance of communication to understand each other and time to gather with family members (family time).

The purpose of understanding here is to get to know the nature and personality of other family members, so as to minimize conflicts that usually occur frequently. The better the accuracy of empathy, the less aggressive behavior will occur.

The results of subsequent interviews, according to the family the use of thetechnique photovoice in increasing empathy attitude is appropriate, the reason with this technique all family members will know the disadvantages and strengths of other families. The changes that families feel after using thetechnique photovoice are more familiar with family members, increasing empathy, reducing selfishness in the family.

Overall this program has been implemented in accordance with the theory and as much as possible. In addition, based on the results of the implementation of this program, it can be concluded that thistechnique photovoice can increase the empathy attitude of the Alas Timur Bawean Gresik hamlet.

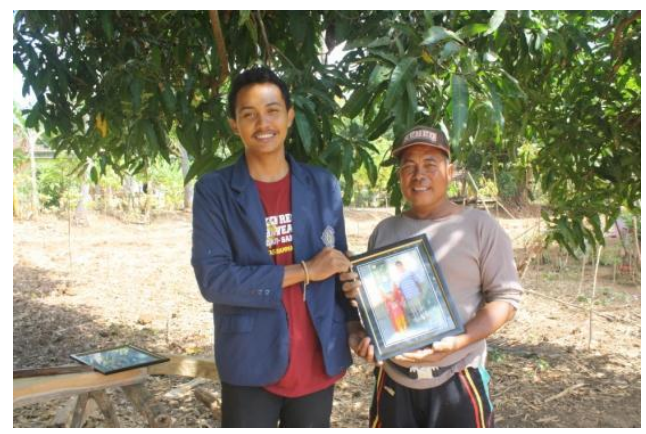

Figure 2. Submission of family photos.

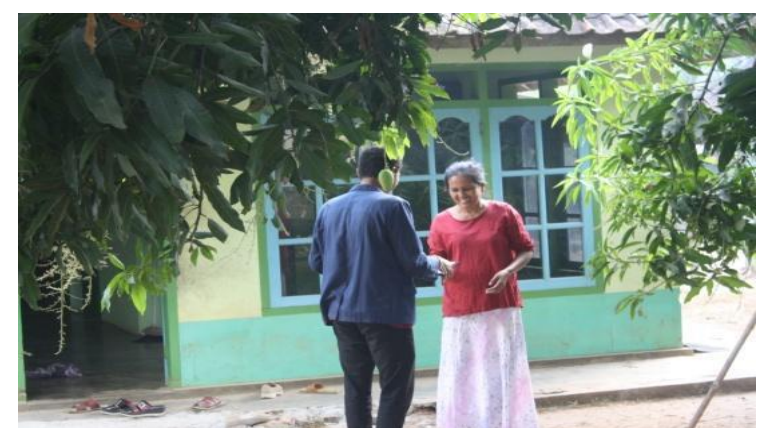

Figure 3. Submission of family photos.

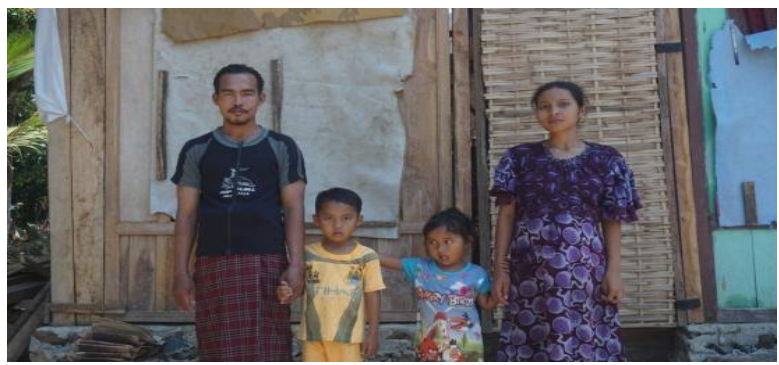

Figure 4. Family photo.

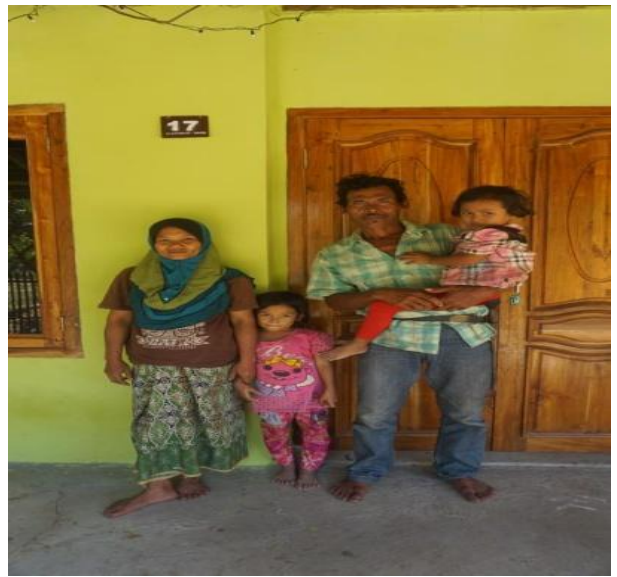

Figure 5. Family photo.

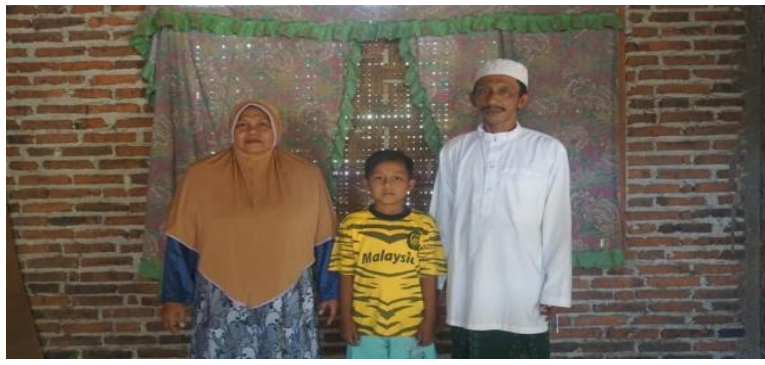

Figure 6. Family photo.

\section{Conclusions}

Based on the description above, it can be concluded that empathy is a psychological process that allows individuals to understand the intentions of other people's behavior, predict the behavior of family members and experience emotions felt by other family members. So as to understand the emotional situation and condition from another perspective 
Based on the results of the implementation of the program that has been done it can be concluded that the lack of communication between family members and lack of time to get together with the family. Not only that, but also the empathy attitude of the Alas Timur Bawean Gresik Hamlet family can be improved throughtechniques photovoice. This can be seen through a comparison before and after the implementation oftechniques photovoice.

The above improvement is also supported by the results of observations and interviews that show changes in empathy, including: families look more concerned both verbally and non-verbally, families are more familiar with the nature and character of family members, families know the strengths and weaknesses of family members and think about what what other family members think and feel.

\section{Suggestions}

From the results of the research that has been described, then there are suggestions as follows:

1. For the family of East Alas Hamlet can improve communication both with family and surrounding families.

2. For families to be able to apply empathy in their daily lives and can also usetechniques photovoice to overcome other problems.

3. For the Head of the Alas Timur Hamlet to support the adoption of thetechnique photovoice in increasing the empathy attitude of the Alas Timur Hamlet Family.

4. For program implementers can be a further consideration to take the same theme. The program implementer can also consider the implementation time on holidays, so that the implementation will be even more maximal.

\section{References}

Anggraini, Dewi \& Cucuani, Hijriyati (2014). Relationship Quality Friendship and Empathy in the Forgiveness of Late Adolescents. Journal of Psychology, 10 (1) $18-24$.

Ernie Ulviatun. (2016). Increasing Empathy Through Photovoice Techniques in Class X. E-Journal Guidance and Counseling for the 5th 10 Year Edition
2016. Downloaded from https://journal.student.uny.ac.id/ojs/in dex.php/fipbk/article/viewFile / 4584/4250.

Handayani, Nurfitri \& Fauziah, Nailul (2016). Relationship of Family Harmony with Emotional Intelligence in Certified "A" Private High School Certified Teachers in the West Semarang Region. Journal of Empathy 5 (2) 408412.

Kandowangko, Nicolas \& Waani, Nelly J (2013). The Role of the Interaction of Family Members in Efforts to Maintain Life of Family Life Haronization in Kumuluk Village, Tiom District, Lanny Jaya Regency. Journal II (4).

Madisa, dena. (2017). The Contribution of Family Harmony to Students' Self Concepts. Indonesian education university.

Manizar, Ely (2016). Managing Emotional Intelligence. Journal II (2).

Saputra, Alvian Teddy Trisna (2017). Photovoice: Method for ImprovingBehavior in ProsocialMiddle School Students. Malang: Thesis. FPSI-UMM. Downloaded from https://www.google.co.id/search?q=sk rypt+photovoice \&client=ucweb$\mathrm{b} \&$ channel $=\mathrm{sb}$. 